\title{
The Persian Mirrors for Princes Written in the Saljuq Period: the Book Series
}

\author{
A. A. Khismatulin \\ Institute of Oriental Manuscripts of the Russian Academy of Sciences, \\ 18, Dvortsovaya nab., St. Petersburg, 191186, Russian Federation
}

For citation: Khismatulin A. A. The Persian Mirrors for Princes Written in the Saljuq Period: the Book Series. Vestnik of Saint Petersburg University. Asian and African Studies, 2019, vol. 11, issue 3, pp. 321-344. https://doi.org/10.21638/spbu13.2019.306

The article begins with a concise description of the genre, period, and classical Persian texts covered by the announced book series of three books: 1) Amir Mu'izzi Nishapuri. The Siyasatnama/Siyar al-muluk: A Fabrication Ascribed to Nizam al-Mulk - this text is still being published and reprinted under the authorship of Nizam al-Mulk, an outstanding Prime Minister of the Saljuqids. However, the results of historical, codicological and textual analyzes show that the text was compiled by Muhammad Mu'izzi Nishapuri, the head of poets department under the Saljuqid rulers Malik-shah and his son Sanjar, and then attributed by him to the dead Nizam al-Mulk with completely definite goals; 2) The Writings of Imam al-Ghazali is a book that includes six texts. Three of them are authentic: a student manual entitled by the author as the Zad-i Akhirat (Provisions for the Hereafter); an authentic part of al-Ghazali's epistle to Sultan Sanjar entitled the Nasihat al-muluk (Counsel for Kings) and a medieval collection of letters addressed by the Imam to various recipients and entitled the Fada'il al-anam min rasa'il Hujjat al-Islam (The Virtues of People [drawn] from the Epistles of the Proof of Islam). The remaining three texts are fabrications; 3) Kay Kawus b. Iskandar b. Qabus. Qabus-nama (The Book of Qabus) and Nizami 'Aruzi Samarqandi. Chahar maqala/Majma' al-nawadir (Four Discourses/The Miscellany of rarities) is a book that includes two authentic texts. After this, the article touches upon the problem of existence of literary and physical forgeries in medieval Islamic literature, their categories and methods of their identification.

Keywords: Mirrors for Princes genre, advice literature, medieval Islamic forgeries, literary fakes, identification of literary fabrications, Nizam al-Mulk, Siyar al-muluk, Siyasat-nama, Amir Mu'izzi, Saljuqs, Saljuqides, false attribution, talbis, tazwir, muzawwir, kitab maj'ul.

Literary works written in the Great Saljuq era $\left(11^{\text {th }}-12^{\text {th }}\right.$ centuries $)$ in Persian in the didactic genre have recently been lively discussed by both Western Iranists and Iranian experts on this period, not to mention Turkish researchers. They have published numerous articles and monographs on this theme, which can be easily found on the Internet, if required. The issues addressed by these works regained importance, most obviously in connection with what exactly is meant by the ideal political model of the organization of Islamic society under challenging modern conditions.

The same complicated political conditions were observed in the Saljuqid period also. If viewed in a schematic and very simplified way, they can be described as follows: the nomadic Turks, who had traditionally kept a well-trained and powerful army, conquered the entire realm of Iran and a large part of the Arab world; the Iranian elite, well experienced

(c) Санкт-Петербургский государственный университет, 2019 
in governing the settled population and collecting taxes from it, served the interests of these Turks and with a good reason considered themselves the actual rulers of the Saljuqid Empire; the Arab caliphs in Baghdad from the Abbasid dynasty essentially acted as the outside observers, being involved in the problems of religion and legalizing the enthronement of the Saljuqid rulers (persian language has already gotten the official status, largely due to the Iranian administration, and gradually became the language of science).

In terms of religion, this period represented the case of a multi-vector religious competition between different creeds (madhhab). The competitive advantage in the rivalry between the Hanafites and the Shafiites was received by those supported by the power in the authoritarian governance system, in the person of the Prime Minister and the Sultan. The predominantly Sunnite administration was tolerant, in general, to the Shiite Muslims, despite the serious opposition of two administrative bureaucracies - the Khurasan and the Iraqi groups. The use of such terminology implied geo-confessional referencing. The Khurasan officials meant the Sunnites of the Khurasan origin, while the Iraqi group included the pro-Shiite descendants from Persian Iraq (Iraq al-'ajam), i.e., the central and northern regions of modern Iran.

The official authorities were not fully loyal to the Shiites. At that time, any of them could first be accused of sympathizing with the Batinites-Ismailites, the ideological alliances of the Shiites and serious opponents of the current administration, and then put to death. Such danger sometimes forced the Shiites to take to hiding their madhhab by using the principle of taqiyya and disguising themselves for the Shafiites, the most Shiite-loyal madhhab among the four Sunni. Therefore, the opponents of both Shiites and Shafiites often used in their religious debates the dual-purpose label "pure/refined" (pakiza) Shafiite.

The Batinites-Ismailites led by Ahmad 'Attash (executed in 500/1107) and Hasan b. al-Sabbah (d. 518/1124) [1] became another key player for quite a long time, openly opposing the Saljuqid vertical of power. Sometimes they were subjected to persecution and elimination, sometimes were used as a tool in the internal struggle for power among the top administration officials. According to Jalal al-Din Muhaddith Urmawi (d. 1358/1979), the editor and commentator of the Persian work Ba'd mathalib al-nawasib fi-naqd "Ba'd fada'ih al-rawafid", written between 556-566 / 1161-1170 by 'Abd al-Jalil Qazwini Razi, a Shiite author of $6^{\text {th }} / 12^{\text {th }}$ century, to demolish the defamation of the Shiites:

Each of the Saljuqid sultans, vazirs and military leaders-amirs, intending to remove his competitor and destroy his rival, conspired with the Ismailites-Hasan Sabbah and his followers - and threw him down with their help [2, i, p.285].

The conclusion of Jalal al-Din Muhaddith Urmawi cannot be extended unexceptionally over the entire Saljuqid top administration, at least because Nizam al-Mulk (k. 485/1092), the prominent Prime Minister of the Saljuqids, and his sons did not conspire with the Ismailites. Therefore, the findings of fact analysis given in both historical chronicles and in the writings of authors belonging to different madhhabs seem more objective.

These [= religious] discords were manifested in various planes. In the cultural plane, there was a struggle that came with the arrangement of dispute meetings, compilation of books on theology and religious ideology for approving or denying of a certain madhhab, establishing educational institutions intended for the followers of specific madhhabs, while the cultural and scientific activity was limited to religious areas and the development of rational sciences was terminated. In the 
political plane, the practice of arranging conspiracies in ministries and at the Court against rivals in the madhhab went at full swing, which made the prerequisites for terror and exile of political opponents. This deprived the society of unity and political independence. In the military plane, the practice of eliminating opponents in the madhhab and terror against political and religious leaders became common, and social security went away from society [3, p. 72].

This made an extremely intricate religious and political background for the appearing didactic texts, which sometimes were actually written by well-known religious and political figures, but more often were attributed to them with quite specific goals.

\section{Literary works included in the series}

The tradition of creating didactic writings goes back to the pre-Islamic era and is analyzed in detail in modern studies [4]. However, in Islamic literature, it acquires its characteristic features. These are directly related to the development of the bureaucratic system and to the facts, by whom traditionally, for whom, and for what purpose were written the texts, which today are referred to the didactic genre. To get a relatively objective view of their specifics at the Saljuqids time, with their branched bureaucratic apparatus, several such texts will be presented in this series of three books. For some of them, Russian translations were published in the mid- $20^{\text {th }}$ century, but these are already outdated by many criteria. Other texts will be published for the first time. However, all of them are part of the classical heritage of Persian literature and its reinterpretation is a natural and unavoidable process, which concerns not only the bearers of Persian culture, who republish these texts with amazing regularity.

The first book of the series - Amir Mu'izzi Nishapuri. The Siyasat-nama/Siyar almuluk (The Book of Government/The Vitae of Rulers): a fabrication ascribed to Nizam al-Mulk - is a classic text well known to every Iranist by the two cited titles. This text was translated into at least 11 languages, including Russian [6], is still published and reprinted in Iran under the authorship of Nizam al-Mulk. However, as demonstrated by the results of historical, codicological, textual and stylometric analysis, the text was compiled by Muhammad Mu'izzi Nishapuri (d. between 518-522/1124-1128) [7], Head of the Department of Poets (the Amir al-shu'ara), under the Saljuqid Sultan Malik-shah (poisoned in 485/1092) [8], and then intentionally ascribed to the murdered Nizam al-Mulk, with a very specific purpose - to obtain a high-status position at the Court of the new Saljuqid ruler. Mu'izzi's innovative idea was to comment on the articles of the legal document, i.e., the labor agreement (muwada'a) of Nizam al-Mulk with the Sultan-employer, with various stories, legends, tales, etc. The main method of compilation was to add this comment whenever possible to every article of the labor agreement. This was how the first redaction of the text appeared. After that the second redaction followed, created by an unknown medieval editor. He reduced the original text, partially edited it and made changes to the foreword, presenting it to be authored by Nizam al-Mulk. These summarized conclusions are drawn from the analysis performed in the Introduction to the translation of the first redaction, in the following sequence:

- a brief overview of previous editions and research findings before and after the discovery of Muhammad Nakhjavani 's copy (Part 1);

- a codicological view of the earliest copies of the Siyar al-muluk (Part 2); 
- a historical context of the appearance of the Siyar al-muluk (Part 3);

- references of independent sources related to the Siyar al-muluk in the authorship of Nizam al-Mulk (Part 4);

- textual analysis of two main redactions of the text (Part 5);

- selection of the articles of the Nizam al-Mulk's labor contract, which formed the basis of the first redaction of the Siyar al-muluk, and were safely retained in the second one, as well.

Here, attention should be paid to the following fact. In the early 1960s, the first report of the unexpected discovery of the Siyar al-muluk oldest copy appeared. This happened amid the international scandal with physical forgeries of ancient manuscripts (see below). According to Hubert Darke, an English publisher of a redaction represented in this copy, it nearly goes back to the autograph of Nizam al-Mulk.

Since my first edition of this text was published in 1962, or rather during the closing stages of its printing, I became aware of the existence at Tabriz, of a manuscript older than any hitherto known. This manuscript, which is preserved in the Nakhjavani collection and housed in the National Library, is dated 673/1274 and in correctness, that is to say credibility, far surpasses all other manuscripts $[9, \mathrm{p} . \mathrm{v}]$.

The discovered manuscript was later entitled a copy of Nakhjavani by the name of its first owner Muhammad Nakhjavani (d. 1341/1962), a famous Iranian philanthropist, collector and bibliophile [10]. His copy represents the second redaction of the text in the authorship of Nizam al-Mulk. Since then, this redaction has played a leading role in further research, both within Iran and beyond.

The second book of the series - The Writings of Imam al-Ghazali (d. 505/1111). For objective reasons, it was published slightly earlier than the first book [11] but I hope it will be republished together with the first book in the series. First, it presents three genuine texts: a student manual under the author's title the Zad-i akhirat (Provisions for the Hereafter); the authentic part of al-Ghazali's epistle to Sultan Sanjar (d. 552/1157) entitled the Nasihat al-muluk (The Counsel for Kings); a collection of Imam's letters to various addressees under the title of the Fada'il al-anam min rasa'il Hujjat al-Islam (The Excellencies of People from the Epistles of the Proof of Islam).

Next to the originals, the book includes three fabrications. The first and the second were created by compiling text blocks from al-Ghazali's original writings with non-authentic inserts. The first fabrication is al-Ghazali's letter to his already consummate disciple, previously considered as genuine, which became known in the Persian original and Arabic translation under two titles - the Ey farzand/Ayyuha al-walad (O child). The second is a compilatory letter to some ruler entitled the Pand-nama (The Advice Epistle). The book is concluded with a text addressed to a certain Saljuqid sultan, which became known both under its own title - al-Farq bayna al-salih wa ghayr al-salih (The Difference between the Pious and not Pious), and as the "second part" of the Nasihat al-muluk, attached to the authentic text either intentionally or mechanically.

The third book to be published in this series will contain two newly translated works of two authors. These are the Qabus-nama (The Book of Qabus) by Kay Kawus b. Iskandar b. Qabus (d. 462/1069-70) and the Chahar maqala (The Four Discourses), or the Majma al-nawadir (The Miscellany of Rarities), penned by Nizami 'Aruzi Samarqandi (d. the sec- 
ond half of the $6^{\text {th }} / 7^{\text {th }}$ century). Throughout the $19^{\text {th }} / 20^{\text {th }}$ centuries, the Qabus-nama was translated into the main European languages from both the Persian original and medieval Turkic translations. The book has been published twice in Russian translation: translated from Tatar by O.S. Lebedeva (1886) and translated directly from Persian by E. E. Bertels (1953). The inclusion of the Chahar maqala, also published earlier in the Russian translation by S. I. Baevsky and Z.N. Vorozheykina (1963), in this book is determined by the small size of this text and inexpedience of a separate book publication under the chosen series format. The reasons for the re-translation and reprint of both works are explained in research introductions to translations in all the books of this series.

Since the announced series deals with both originals and fabrications, it makes good sense to give a clear definition of what is meant by fabrications and whether such understanding was characteristic of Islamic literature of the Saljuqid period, as well as to raise the issue of categories of fabrications and ways of their identification.

\section{Definitions of fabrications}

In modern scholarly publications, the reader can occasionally come across a work, which is attributed to some author by the researchers, implying the probability of false attribution. This wording suggests that the authenticity, or originality of the authorship is not identified, or not proven, or uncertain. To emphasize the fact of uncertain or yet still unclear authorship, the prefix "pseudo-" is sometimes added to the author's name.

Falsely attributed works are found in every cultural tradition. It can be even said that their presence is an integral element of culture, arising, as a rule, for two reasons. First, when in the absence of a direct indication of authorship, historians and literary scholars, relying on some indirect signs, begin to consider a particular text to be written by a certain author. Secondly, when someone, having written a certain text, intentionally concealed his authorship and attributed it to another person, pursuing his goals. As a result, a text with false attribution emerges, which in the second case is burdened by the fact of forgery. It is not uncommon that a comprehensive text analysis reveals both causes, i. e., researchers attribute the text to the same person the forger attributed it. Therefore, in this series, forgeries, or fabrications denote texts with false attribution, which were accidentally or intentionally attributed to persons uninvolved in creating these texts.

It is well known that the creator of any forgery (paintings, jewelry, banknotes, etc.) follows the already preset and recognizable sample of the original, trying to bring it as close as possible to the latter with minimized costs of production. At the same time, the methods used to manufacture fabrications are very similar in appearance to those of creating originals and the costs are minimized through falsification of uniqueness by copying it in order to extract the maximum profit. To produce successful falsification, the creator of a fabrication should have expertise in his sphere: to study the form and genre of the author, his manner, stylistic features, etc., in order to be able to copy them further and present them as genuine.

The same is true for fabrications of medieval scholarly writings. The main objective in identifying such fabrications is to detect alien fragments, to separate them from those original (if any), to prove their inauthenticity and ultimately to determine the purpose of creating a fabrication. 
A fabrication is the same cultural artifact as any other, but made with special purposes. That is why, in order to definitively prove the falsification of an artifact, it is necessary to show absolutely clearly and convincingly the purpose, for which this fabrication was done [12, p. 341].

Taking a fabrication for the original in scholarly research, making conclusions and building the entire theories upon it, many modern authors prefer sometimes to keep silent about the fact that they deal with a fabrication, made intentionally by someone for mercenary, ideological or other reasons. The longer this fact is concealed and the more researchers do prefer it, the higher the probability of the future unspoken consensus about the authenticity of the fabrication is. Quantity is transformed into quality. In the future, a noncritical attitude towards it will eventually form a historical myth, with many generations of scholars believing it, defending their MS, $\mathrm{PhD}$ and doctoral research works, publishing articles and monographs.

It is good if a fabrication was unmasked without delay, shortly after the publication. It has no time to enter the mass circulation and to fool many innocent people. But more often the opposite happens. A sensational document gets widespread, receives coverage from the sensation-seeking mass media, thereby rooting it in the mass consciousness. To discredit such a time-tested "source" is very difficult $[13$, p. 9$]$.

Refusing the established myths is not only "very difficult", but is always extremely painful, and sometimes just uncomfortable. However, as practice shows, the facts of fabrications, both modern and medieval, are convincingly revealed sooner or later, and myths have to be refused. There is no doubt that with evolving digital technologies and digital humanities, the number of identified fabrications will only increase, leading to a revision of previous ideas, as well as the inevitable fall of many myths that still exist in any culture. This trend is already well traced in identifying fake news in modern mass media.

\section{Medieval fabrications}

There are enough facts that suggest that the fabrication of texts with their ascribing to famous people was not a rare phenomenon in medieval Islam. An illustrative example of circulation of deliberate fabrications and false attributions in the Islamic written tradition is the presence of a vast corpus of statements-hadiths included in the category of forgery al-hadith al-mawdu'. For various reasons and for different purposes, their authorship was attributed (sometime and by someone) to the Prophet, and their definition was made exactly by Muslim researchers. The same can be said about the so-called 115th Surah of the Quran created by someone. If the end justified the means for the Prophet's statements and even for the Quran, then what can we say about other authors and their writings.

The most remarkable cases of medieval fabrications in the Persian written tradition are related to the work of poets, whose names are familiar not only to the Iranians. These are: a large number of quatrains attributed to 'Umar Khayyam (d. 510/1131) [14], the seventh daftar of the Mathnawi created by someone and attributed to Jalal al-Din Rumi (d. 672/1273), etc. Almost every popular medieval Persian poet became a posthumous owner of poems, which he had never composed and whose authors could hardly ever be identified.

Modern scholars will have to look more closely and systematically at what their medieval colleagues wrote about fabrications and do not limit themselves to addressing this 
topic only in connection with physical fabrications ${ }^{1}$. For instance, Imam Muhammad alGhazali tells of three attempts to forge his works. On the frontispiece of the first, authentic part of the Nasihat al-muluk addressed to Sultan Sanjar, the Imam makes a written note, which is further included as the third letter in his epistle collection entitled the Fada'il alanam min rasa'il Hujjat al-Islam, telling as follows:

Envy leaped in the envious. They found no other acceptable [way of] defamation, except for making falsification (talbis): in the book al-Minqidh min al-dalal and in the book Mishkat al-anwar, they changed several phrases, added phrases of disbelief and sent me to write a written permission $(i j a z a)^{2}$ on their frontispieces. The Exalted and Holy Worshipped, by His mercy and generosity, honored me the intuition to study them and realize their falsification.

Later, this case became known to the Head of Khurasan. Having arrested the counterfeiter (muzawwir), he eventually sent him out of Nishapur, after which he went to the headquarters of the Lord of Islam and wagged his tongue of defamation, but was powerless. Then he took the synopsis, which I had done in my youth and wrote al-Mankhul min taliq al-usul on its frontispiece. As early as thirty years before, those envious added to this synopsis a number of phrases condemning Imam Abu Hanifa [11, pp. 116, 184].

As seen from this passage, one of the three attempts was successful. If such attempts were made during the life of al-Ghazali, we can imagine what happened after his death. In the words of the Imam, the counterfeiter was arrested but soon released. In other words, creating fabrications was considered a wrongful act already in those times. Even then, it was condemned and entailed punishment in terms of the Muslim law. Under the legislation, fabrications were called by the terms talbis ('falsification') by editing the author's text and tazwir ('fabrication'), and their creators - by the term muzawwir ('counterfeiter').

In their writings, our medieval colleagues also mention rather often the cases of outright plagiarism that took place in their surrounding. Plagiarism was defined by the Arabic term al-sirqa ('theft'). So, al-Hujwiri, the author of the pioneer Persian compositions on Sufism, the Kashfal-mahjub (The Revelation of the Veiled) dated the late $5^{\text {th }} / 11^{\text {th }}$ century, complains that the only copy of his collection of poems was stolen by his contemporary, who appropriated the authorship to himself. Al-Hujwiri also speaks of the fortunately failed attempt to replace his name as an author with another in the work the Minhaj al-din (The Highway of religion).

The desire to put on my name at the beginning of the book was twofold: one is a lot of the experienced, the other is a common lot. As regards the common lot, it is that when persons ignorant of this knowledge see a new book, in which the author's name (musannif) is not set down in several places, they attribute his work to themselves, and thus the author will not reach his goal. After all, the desire to collect (jam), compile (ta'lif) and compose (tasnif) is only that the author's name would be kept alive and that readers and students would pray for his good thanks to his book.

It happened to me twice. Once a man asked me for a collection of my poems (diwan) and kept it in his possession, and its original was in a single copy. He rewrote everything in it, struck out my name from the title and nullifying my labor. May Allah forgive him! I also wrote a book

1 An overview of the problem in the Persian cultural tradition, with reference to particular cases of physical forgery, see the collective article Forgeries on the Encyclopædia Iranica website [15].

${ }^{2} \mathrm{Ij} \mathrm{a} \mathrm{z} \mathrm{a,} \mathrm{or} \mathrm{khatt}-\mathrm{i} \mathrm{ija} \mathrm{za}$, is a written permission from the author, verifying a copy of his work and actually turning it into the original ( $a s l$ ). This procedure is somewhat similar to the modern notarization of document copies; in the Middle Ages, it was made on the frontispiece of a manuscript - a space reserved for various inscriptions. 
about a method in Sufism entitled the Minhaj al-din. A shallow pretender, which is not worth talking about, erased my name from its title and presented it to the public as if he had written it himself, although connoisseurs laughed at his words. [17, pp. 1-2 $]^{3}$.

The cases of such illegal actions can be found in every epoch. The famous Shafii scholar Jalal al-Din al-Suyuti (d. 911/1505) was struck by the case of open plagiarism that had happened to him and even wrote a short essay on this topic entitled al-Fariq bayna'lmusannif wa'l-sariq (The Differentiator between the Composer and Plagiarist).

These facts clearly indicate that deliberate forgery and plagiarism were common in medieval Islam, referring to illegal, blamed and punishable acts the same way, as it is now. Despite the formal resemblance, plagiarism should be considered separately from fabrications. After all, in the case of plagiarism, we face a trivial theft, while in the case of intentional fabrication we still encounter creativity, albeit specific. The persons involved in such creativity used either the name of a famous author, or his intellectual property, or both, resorting to various methods and techniques.

To identify fabrications, first of all, we need to know the traditional forms of creativity in the scholarly literature of the Islamic Medieval Ages. Knowing the form of creating a work with doubtful authorship, it can be subjected to the textual analysis, comparing its content, logic, presentation style, etc., with a reference work, i.e., a guaranteed authentic text (or better, texts) written by the author in the same form and genre.

\section{Forms of medieval scholarly literature}

The same way as there are modern templates and recommendations for writing MA, $\mathrm{PhD}$ and doctoral theses, the main forms of writing scholarly books are identified in the texts of medieval Muslim scholars. There are three of them: collecting (jam) of material, its compiling ( $t a^{\prime}$ lif) and composing, or systematization/classification (tasnif). These three terms are mentioned in the above passage from the Kashfal-mahjub by al-Hujwiri. These forms were common in almost all genres of scholarly literature of the time: hagiographical, historical, theological, etc. Sometimes the first two terms, jam' and ta'lif, are found together in the author's preface. However, the collection of material was often meant as a natural preparatory process prior to its compilation and in this case, only ta'lif is mentioned in the preface or across the text. Tasnif represents an entirely different, independent form of scholarly creativity. The same applies to the author, who chose one of the forms to write his text. He was called either the collector - jami', or the compiler - mu'allif, without any negative connotation, or the composer/systematizer - musannif, respectively. The key difference between these forms lies in the proportion of synthesis and analysis.

The primary ta'lif: the source for the compilation is mostly oral tradition, i. e., the compiler collects material for his work mainly from living informants or from his notes and memories - reminiscent of the modern field research associated with interviewing respondents. Then he has to allot (takhsis) the collected material and arrange it, following the genre pattern preset by the existing literary tradition. After that, he is quali-

3 An English translation: The Kashf al-mahjub. The Oldest Persian Treatise on Sufism by 'Ali b. 'Uthman al-Jullabi al-Hujwiri, transl. by Reynold A. Nicholson, Leiden, Brill, 1911; a Russian translation from the English translation: Ali ibn Uthman al-Hujwiri. Raskrytie skrytogo za zavesoi. Stareishii persidskii traktat po sufismu, tr. from English by Orlov A., Moscow, Edinstvo, 2004. 
fied for giving a title to his text and to write a foreword. The main objective of the primary ta'lif is to collect, compile, minimally arrange the material according to a given pattern and introduce it in this form into the written tradition. It holds the maximum information transfer and the minimum of its analysis and own comments. That is why primary ta'lifs are mostly characteristic of the hagiographic, or saints' vitae, literary genre - maqamat, tadhkira, manaqib, etc.

The secondary ta'lif: the working algorithm is the same as in the case of the primary ta'lif, but with one fundamental difference: the source of the material for compilation is mostly the written tradition, i. e., ta'lifs and sometimes the tasnifs of the predecessors. The main objective of such a ta'lif is a thematic collection of information taken mostly from written sources. That is why the secondary $t a$ 'lif is the most common form of medieval scholar creativity. It covers almost the entire genre spectrum. In some genres (for instance, hadith studies) a compilation can include not a single word from the author except for the preface, sometimes formal, and sometimes even lacking.

The originality of such ta'lifs is represented, firstly, by the author's selection of sources. This collation is intended to clearly demonstrate the reader that the compiler belongs to a particular religious law school (madhhab). For instance, a Sunni hadith scholar will not use the Shiite collection of hadiths for his ta'lif save for the genre of refutation (radd). Secondly, the minimum analytics appears in the secondary compilation - the compiler arranges the selected material, following the preset logic and the genre pattern, and determining its vector. For example, two vectors are distinctly traced in the hadith literature - either uniting all multi-thematic statements from each hadith carrier, or arranging statements from different carriers according to the thematic principle. In the historical compilation (tarikh), there are also two vectors: fixing the chronology of events with a tendency to expansion and adding current events by the subsequent historians, or conversely, a tendency to reduce the material presented by the predecessors; in the genre of commentary (sharh) or refutation ( radd) - expansion of the primary text by consecutive commenting on each thematically complete statement with quoting other texts and statements on the same theme, etc. In other words, the literary template of the secondary compilation has already its own established genre vector to be followed by the compiler [19].

The emergence and evolution of the secondary ta'lif as a form of scholarly creativity should be linked, apparently, to the system of traditional Muslim education, where the key feature was studying, note-taking, or even memorizing the books of particular scholars under the guidance of experienced mentors. Such ta'lif resembles collecting mosaic elements, when each compiler can compose his own pattern from the material studied (lecture), and/or material available or newly-entered the intellectual market (books), according to the template already defined by the tradition. In today's reality, this ta'lif is similar by its structure and approach to the MA work in humanities, with a series of quotations from various studies and bits of the author's own thoughts, or a $\mathrm{PhD}$ thesis with the same bulk of quotes and minimal analytics.

Tas $\mathrm{n}$ if represents a top performance of analytical thought that requires an extraordinary level of training and, in the context of medieval science, a high religious status of the author (musannif). In the modern reality, tasnif is an ideal version of a doctoral thesis. Not surprisingly, this term is used as part of nominal predicate to refer to music and verses - 'to compose verses, music', i. e., to create something original. Even with the abundant quotations cited as illustrative and evidentiary base, the analysis holds a promi- 
nent place in tasnif. Sometimes it can occupy up to one third of the text, which is quite consistent with the ratio between synthesis and analysis in modern analytical studies. The main objective of tasnif is to propose a new idea, break down the existing patterns and show a new facet of the object under study by applying an innovative approach (declarative or actual), which is unfailingly mentioned by the author in the preface or in the text of the book. At the same time, the author's references to the tasnif written by another author should be taken critically. They were often made just to show respect or to emphasize his high religious status [20].

\section{The main categories of medieval fabrications}

Fabrications can be classified into three categories, which were made in three main ways and appeared periodically on the intellectual market of medieval literature. The methods of their production are very similar to the forms of scholarly creativity described above.

1. Intentional attaching a non-authentic text to the genuine text is the most common and easily recognizable method. It was mentioned by al-Ghazali in the case of al-Mankhul min ta'liq al-usul, it is also reviewed in the first book of this series in connection with the addition of a non-author comment to the Nizam al-Mulk's labor contract and the addition of 11 new chapters in the end, as well as in the second book of the series in connection with the "second part" of the Nasihat al-muluk. The cases with the seventh daftar of Mathnawi, which once was attempted to be added to the six genuine daftars, and the $115^{\text {th }}$ surah of the Quran also refer to this category.

This method goes together with the quite traditional and legal manner of writing secondary ta'lifs, in particular, historical chronicles and anthologies. The text was frequently updated on a chronological basis by another author taking from the place where his predecessor had stopped. If apply culinary definitions, a fabrication created by this method can be compared with a two-layer pie, where each layer is created by a separate baker. Also, here are occasional copyist errors, when the title is skipped and a colophon is absent. As a result, when the text of one author was unintentionally, due to the human factor, added to the text of another author and was passed to further copying or translation in such an "updated" form. Therefore, when identifying a non-authentic part attached at the end, which sometimes is not even styled as authentic, the key question for further investigation is whether the attaching occurred accidentally or intentionally.

2. Purposeful compilation of text blocks taken from the original writings of a famous author, with non-authentic text blocks, in order to create the illusion of authenticity and achieve personal goals by appealing to the author's influence. Such fabrications were almost always created deliberately, followed a specific plan and pursued specific goals. The illustrative cases are given in the second book of this series, two forgeries attributed to al-Ghazali: the Ey farzand/Ayyuha al-walad (O child) and the Pand-nama (The Advice Epistle).

Fabrications included in this category are similar to multi-layered pie and are the most difficult in terms of validating their inauthenticity. After all, it can be argued with good reason that the author changed his point of view to a certain subject over time, or completely revised his views, especially when there is an underlying formal reason to do that. Thus, the authenticity of many texts attributed to al-Ghazali, or are deliberate fabrications, is validated only upon the revision of the Imam's views caused by his spiritual crisis and the subsequent withdrawal from active social life, without giving more weighty arguments. 
Obviously, if such a multi-layer compilation is not attributed to anyone and has a unique author's title and preface, it is completely legal and created in the form of a secondary ta'lif, full of quotations from various sources. At the same time, it cannot be ruled out that this was made by the forger - he, instead of the author, gave the title, wrote the preface and filled the text with quotations he needed. This similarity of methods of creating original compilations in this category and their fabrications is the reason, why so many medieval fabrications survived to the present day and remained undetected.

Apart from the typical compilations, private correspondence and official documents were most prone to this way of falsification. After all, the forger did not need to name them and write author's prefaces. The epistolary genre did not assume this and the documentary genre in every epoch and under every Muslim dynasty had its own strict template to be only followed. Moreover, the texts created in these genres, for obvious reasons, seldom entered the book market and did not require written verification from the author (ijaza), i. e., they had no barrier to protect them somehow against fabrications.

3. Deliberate editing of the text content, when adding or removing the negation is enough to change the meaning to the opposite, not to mention the more complicated intellectual editing, as described by al-Ghazali in the case of al-Minqidh min al-dalal and Mishkat al-anwar. Such fabrications resemble a pie with an inauthentic filling. This also includes casual errors of copyists.

To identify fabrications made this way, it is sometimes enough to prepare a critical text based on several versions, which will make it possible to identify non-author's editing.

\section{Physical forgeries}

The issue of physical forgeries of manuscripts would not have been the subject of discussion here, unless it had affected two texts from the announced series: partially - the text presented in the first book, and directly - the text scheduled for publication in the third book. That is why this problem could not be ignored.

The specifics of any forged manuscript is not only in claiming its physical uniqueness (the most ancient, an autograph, or a copy of an autograph copied by a famous calligrapher, etc.) but the fact that it always represents some redaction of text. This makes the major scholarly problem of physical forgery. The text of the "unique" manuscript is considered as more reliable after its publication and presentation, and noticeably influences the nature of further research until it turns out that the manuscript where it was presented was fabricated.

The problem of physical forgeries in the Iranian cultural tradition in general, and in manuscript studies in particular, is under the scrutiny of the Iranian scholars. It stood out most acutely by the late 1950s. At that time, several allegedly ancient manuscripts were purchased for a large amount of money by well-known manuscript repositories in the USA, Europe, and Iran itself. Additional expert examinations revealed that the manuscripts had been made in contemporary workshops in Iran. A scandal broke out, in which well-known Iranian, Western and even Soviet scholars were involved and harmed, one way or another. Discovery of numerous (though, obviously, not all) fabrications also revealed that people involved in their production had been active in this trade for over twenty years, i. e., approximately from the beginning of World War II.

At that time, an increased demand for antique manuscripts emerged in Iran. Here, the capital law should be emphasized: the forgery business would not have achieved such 
a huge scope without market demand. It was fueled by both collectors and the scholarly community. From the end of the $19^{\text {th }}$ century, the latter experienced an acute shortage of available medieval texts in need to be published. Market demand begot local craftsmen. They started to professionally satisfy it both within the country and abroad, until the early 1960s. At first, it was more domestic-oriented, apparently triggered by local collectors and the need to fill up the manuscript collections of recently opened libraries (e.g., the National Library of Iran, 1316/1937) with valuable copies. Later, the forgery business expanded, going beyond the borders of Iran and starting to meet the external demand for rare books.

To represent the scale of disaster from physical forgeries, which seized at that time international Iranian studies, a brief critical note by Mujtaba Minuwi (d. 1355/1977), a well-known Iranian specialist in textual and manuscript studies is given below [21]. The reason for its publication originated from the publication of the Ruba'yyat (Quatrains) by 'Umar Khayyam in the USSR. As far as I am aware of, this article has never been translated into Russian or English; therefore, here its full text is provided.

A note by the expert Mujtaba Minuwi on the number of the forged manuscripts [22]

A critical note ... about the printed version of Ruba'yyat (Quatrains) by Khayyam, which was published in Soviet Russia [23], provides an opportunity to write and communicate to the public a few words regarding the copy, which was published as a facsimile together with this publication.

In the past twenty years, a number of manuscripts have been put for sale to public libraries and individuals in different cities, which were sold for large sums as "ancient manuscripts". They have dates and colophons that indicate their antiquity, but actually they are fabrications and forgeries that gained publicity and led to the deception of a group of individuals.

1. A copy of the Andarz-nama (The Book of Advice) by Kay-Kawus, about which I published an article entitled "Kapus-nama-yi Frye" in the journal Yaghma [24].

2. A copy of Diwan of Qatran Tabrizi, "copied by Anwari," about which Mr. Dr. Mahdi Bayani wrote an article published in the journal Yaghma [25].

3. The book al-Hidaya wa'l-dalala (The Right Guidance and Deviancy), a work by Sahib Ibn 'Abbad, published as a separate risala by Mr. Husayn 'Ali Mahfuz [26].

4. A copy of the Ruba'yyat by Khayyam, dated $658 \mathrm{AH}$ and owned by Chester Beatty library. Mr. Professor Arthur J. Arberry published the Rubayyat upon this copy [27].

5. A copy of the Ruba'yyat by Khayyam, dated $604 \mathrm{AH}$ and kept in the library of the University of Cambridge. Initially, this copy belonged to the late Abbas Iqbal Ashtiyani and was presented in the pages of Yadgar journal. Its photocopy supplemented with a French translation was published by Pierre Pascal [28], and a photocopy from it was also published in the Russian edition. It was also used in the German translation of the Rubayyat by Khayyam, recently published in East Germany.

6. A copy of the Ruba'yyat by Khayyam belonging to the library of Mr. Engineer 'Abbas Mazda and dated $654 \mathrm{AH}$, a complete photocopy of which I have seen.

7. A copy of the Ruba'yyat by Khayyam, dated $619 \mathrm{AH}$ and kept with an American antiquarian in New York, a photocopy of a page of which I have seen.

8. A copy of Diwan by Mu izzi, which was sold as "a copy of a contemporary of the poet" and taken to the US. Later, they complained it was a fabrication.

9. A copy of the Miraj-nama (Book of the Ascension) attributed to Ibn Sina, dated $584 \mathrm{AH}$ and located among the books of Dr. Mahdi Bayani, a facsimile of which was published by him under the title "Fakhr Razi's handwriting" [29].

10. Al-Munajat al-ilahiyyat 'an Amir al-mu'minin (Divine intimate conversations by the Amir of believers), which were published by Fakhr al-Din Nasiri in offset printing in 1340/1961. 
Three or four more copies of the Rubayyat by Khayyam, the Khalas by Natanzi and something else that was sold to the National Library about twenty years ago and is now there should also be added to this list. The calligrapher who made these copies, or most of them (dated from 485 to $658 \mathrm{AH}$ ), is the one and the same person who is still alive.

All these manuscripts are products of a workshop that has been operating in Tehran for twenty years. One or two calligraphers, one paper maker, a broker and a salesman responsible for selling antiques managed the workshop, making their craft a fraud of a group of gullible people: they once earned seventy thousand dollars at one American, once fifty thousand tumans at Tehran University, offering falsehood, a fabrication and paper making. If they hadn't been brought to clean water, they would have continued to steal and cheat.

I know nothing about the laws related to the forgery of such documents. I do not know whether the Prosecutor or private prosecutors can sue and punish the sellers, copyists and manufacturers of these books. But I know that their activity will result in enormous damage to Iranian literature. It has already resulted ${ }^{*}$. The culture authorities should take serious measures, publicly and openly inform everybody about the falsification of these books and oversee that manuscripts of this kind are not bought in the future, and this structure vanished.

I am not afraid to publicly disclose without reserve the names of several falsifiers, deceivers and fraudsters engaged in such activity earlier and at the moment. ${ }^{4}$ However, if, after a huge scandal and a court trial they are acquitted, I am presented as a slanderer, and the books they have fabricated are meanwhile recognized as uninvolved in the slander, then it is better they remain unknown and people only get familiarized with the books.

Mujtaba Minuwi

27 Urdibihisht 1342 [= April 18, 1963]

* The Society of National Monuments has already made a number of errors in the epitaphs on the pedestal of Khayyam's tomb. It was redirected to a copy of Khayyam published in Russia. The appearance and handwriting of these epitaphs is similar to the appearance and handwriting of a large format in a forged copy of the Ruba'yyat by Khayyam, dated nine-hundred-odd $\mathrm{AH}$ and sold twenty years earlier to the National Library.

Details of the emergence and development of the crisis related to physical forgeries are given in one of Mujtaba Minuwi's letters. The letter was first published in the Khandaniha (Worthy Fiction) publicistic magazine which was issued intermittently from 1319/1940 to 1358/1979. Clippings from this magazine were found in the personal archive of Mas'ud Farzad (d. 1981), researcher of Hafiz and Khayyam works, literary scholar and translator. The archive consisting of materials for research, letters from colleagues and diaries was found after the owner's death in the cell of the National Bank of Iran, in Shiraz branch. Part of the materials was published in 1999, including an excerpt from Minuwi's letter.

Minuwi wrote his open letter after the publication of the above-mentioned "Critical note" in response to the accusations of his colleague that it was because of him that Iranian orientalists suffered image losses, in particular, in the eyes of Soviet Iranists, and that since he himself initially took the first fabrication for the original, he himself should compensate for material damage to the University of Cambridge. Here some discrepancies in the dating of individual fabrications compared to that mentioned in the "Critical note" should be disregarded, because Minuwi obviously wrote on a topic that was emotionally colored for him and such circumstances sometimes lead to inevitable errors.

4 The names of the organizers of this family business have already been named in the Minuwi article [24, 456-457], but, apparently, his first exposure did not harm the falsifiers, who are also mentioned in the article by Francis Richard [15]. 
You have touched on the matter with the copy of the Rubayyat by Khayyam. As you may know, this copy belonged to the late Abbas Iqbal. It was presented to him by one of his friends (perhaps the one who made and fabricated it). Iqbal personally presented it in the Yadgar journal, and then, having arrived to Paris on a business trip, offered it to customers in London with my mediation. Without assuming any responsibility and not acting as a guarantor of its genuineness and authenticity, I handed it to the buyer, becoming an intermediary in delivering money to the late Iqbal. Here it is necessary to give an explanation: at that time I considered this copy genuine, ancient and authentic. But when the number of such copies increased further (Khayyam, dated 613 AH, in New York; Khayyam, dated 653 AH, with Mr. 'Abbas Mazda; Khayyam, dated $658 \mathrm{AH}$, in the Chester Beatty library; the Qabus-nama, dated $483 \mathrm{AH}$, and seventeen-eighteen other copies - all written by one person and all came from the same workshop), I was convinced that they were fabrications.

I openly announced their fabrication and forgery in 1960 in Washington. In the same year, at the Congress of Orientalists in Moscow, I saw that Mr. Aliyev published the same copy of Khayyam in the form of a facsimile, issuing a typesetting text and a Russian translation on its basis, because considered it authentic and genuine. Being there, one day at the ad hoc meeting I told the sixteen or seventeen attending Tajik, Russian and Caucasian Iranists for two hours and fortyfive minutes about a copy of Khayyam and other forged copies that appeared on the market over the past twenty-plus years and recognized by a number of persons, proving with hard-hitting arguments and evidence that these copies could not be taken as a sample when publishing texts. One of those present was the same Mr. Professor Aliyev, who is now in Tehran. You can ask him.

Therefore, I was the first to announce the forgery of this copy. Thanks to the article I published about a fabricated copy of the famous Qabus-nama, everyone's attention was drawn to this copy-making workshop. If Mr. Aliyev said anything about this, he should have said in such expressions: "I considered this copy [of the Ruba'yyat by Khayyam] authentic, but one expert from Tehran University dispelled my misconception".

After that, this issue was again discussed in the Rahnama-yi kitab (A Guide to Books) journal, where I gave a list of ten to twelve fabrications, indicating that part of these books were purchased for a considerable price by the Ministry of Culture and the other part - by the University of Tehran [see above] ... [30, pp. 192-193].

Here a number of historical references should be given.

1. In August 1960, the $25^{\text {th }}$ International Congress of Orientalists was held in Moscow.

2. Minuwi took for the original not only the copy of the Ruba'yyat by Khayyam, but also the forgery of the Qabus-nama [31], dated 483/1090, illustrated with miniatures and mentioned as the first item in his "Critical note". This happened back in 1950. Here is what he writes:

In 1950, I personally saw two pages from this book in Paris with the late 'Abbas Iqbal Ashtiyani, who brought them perhaps to sell in Europe. He said that the copies belonged to one of his friends, who asked five thousand GBR for them. I saw these two pages for some ten minutes and, without bothering to analyze them somehow, was deceived by their appearance and did not doubt their authenticity. A few weeks later, Mr. Prof. Reuben Levy made a presentation about Qabus-nama to the Iranian Society in London. Upon the end of his presentation, I openly announced that a copy of Qabus-nama, dated $483 \mathrm{AH}$, was found and that it would be proper if $\mathrm{Mr}$. Levy puts it as the core of his publication [24, p. 451].

3. Later, Minuwi became doubtful about the authenticity of the "ancient" manuscripts, which popped up in Iran like mushrooms after a rain. In 1952, he openly warned Richard N. Frye (d. 2014), a relatively young American Iranist with mini- 
mal experience in manuscript studies, that he should not buy manuscripts from a famous Iranian family with whom Minuwi was personally acquainted and knew about their trade.

But Frye really should not hold a grudge against anybody but himself. Because in 1952 and 1953, when as a guest of the University of Tehran he lived as a student in this city and, incidentally, was looking for rare manuscripts - I guarded him against, discouraged and warned him to refrain from manuscripts that come out of the hands of certain people and a famous family, God forbid, he would be deceived. Instead of displaying vigilance, Frye just conveyed my words openly to the very person I had warned him against, putting me in a difficult position to respond to his claims. One or two months after, Mr. Frye returned to the New World with a copy of Diwan by Mu'izzi, for which the sellers took a significant amount from him [24, p. 452].

4. After a forged copy of the Diwan by Mu'izzi, dated $551 \mathrm{AH}$, richly illustrated with miniatures, was officially purchased by the Houghton Library at Harvard University (MS Typ 1016 at Houghton Library), upon the advice from Frye, the examination of miniatures and chemical composition of paper and ink was completed there by 1954 . The experts failed to issue an unambiguous verdict upon the chemical composition of the paper but the miniatures and the blue ink color used in the manuscript were recognized as fabrication with confidence [33, pp. 87-91]. Export permit for the copy was issued by Dr. Mahdi Bayani (d. 1346/1967), the founder and first director of the National Library of Iran and a part-time head of the expert council on values at the Ministry of Culture. In $1331 / 1952$ he already knew for certain that this manuscript was a fabrication, otherwise he would not have given export permit, which he wrote in response to Frye's written claim:

You know, if we considered the copy of the Diwan by Mu'izzi to be genuine and ancient, we would not be able to give permission for its export. You did not ask our opinion on its authenticity or forgery, but only asked export permit, which we gave you. You will have to take responsibility by yourself, whether it is an original or fabrication $[24,453]$.

5. The fabrication of the Qabus-nama was sold by forgers by parts and in 1953 was already smuggled into the US by the authorized agents of two buyers. One part went to the collection of the Museum of Cincinnati, the second - to the collector, Hagop Kevorkian (d. 1962) to New York. Richard Frye became famous for buying a "rare" manuscript for Harvard and later, following the instructions from Kevorkian, toured across the Middle East countries in search of antiques and came again to Iran in 1953. That is why Minuwi at first was mistaken that the Qabusnama was smuggled out by Frye.

6. In 1954-55, Walter Bruno Henning (d. 1967), one of the leading experts in the pre-Islamic history of Iran [34] and Minuwi's teacher revealed the forgery of the Qabus-nama upon the philological text analysis. He wrote a letter to Minuwi with the results, asking him to publish these findings without mentioning his name. Minuwi did just as requested in a famous article, "Kapus-nama-yi Frye", taking Henning's letter as a baseline.

7. Following numerous articles published in Iran, mutual accusations and excuses, as well as the publication of official documents in the international scientific jour- 
nal Nama-yi Baharistan, the latest purchase details of the fabricated Qabus-nama and Diwan by Mu'izzi surfaced in Frye's autobiographical memoirs [35].

8. 'Abbas Iqbal Ashtiyani, a distinguished historian and specialist in textual studies, died in Rome in February 1956 [36], did not see either the first or the subsequent Minuwi's revelations, but he was probably aware of news from the US. Apparently, the forgers used him "blindly" to their advantage, without his knowledge, to search for buyers abroad. Most likely, he, just like Minuwi, took the fabricated copy of the Ruba'yyat by Khayyam presented to him for the original, which speaks only of the high level of fabrication manufacturing.

9. Relying on in-house observations and the available works of foreign colleagues, Iranian scholars from the National Library of Iran carried out studies on the classification of the main external signs of physical forgeries. The research results, supported by illustrative examples, were recently published [37, 265-291]. Unfortunately, certain external features of fabrications listed in the study, can no longer serve as indisputable evidence for their identification, though are quite capable of attracting attention and transferring the manuscript to the category of "uncertain".

\section{Operational aspects of a forgery workshop}

The bare facts below provide an opportunity to note some business details of forgers of medieval manuscripts in the mid- $20^{\text {th }}$ century.

\section{List of productions}

Calligraphers of this team felt more confident in forging the manuscripts of mainly Persian-language writings of the Great Saljuqs reign (431-552/1040-1157): the Qabus-na$m a$, allegedly copied in 483/1090, the Rubayyat by Khayyam (d. 510/1131), part of the Diwan by Mu'izzi (d. between 518-522/1124-1128), part of the Diwan by Qatran Tabrizi (d. 465/1072), allegedly copied by Awhad al-Din Anwari (d. 585/1190), al-Khalas by Adib Natanzi (d. 497/1103 or 499/1105) [38]. They obviously preferred the Saljuqid epoch because of the high cost of literary works of this period in the book market, which does not exclude deviations in one direction or another. Dates of the copied writings in the discovered fabrications cover a period of slightly less than two centuries, from 483/1090 to $658 / 1259-60$.

\section{Distribution}

Three features of finished products distribution are seen most clearly:

- a fabricated copy could be sold both as a single piece and by parts;

- the main customers, both domestic and from abroad, were private collectors and manuscript repositories;

- since the early 1950s, when the workshop business entered the international level, the forgers took to conspiracy, when foreigners were the first to get news about the workshop products, instead of Iranian scientists;

- the sale of the manuscript by parts, as well as Minuwi's references to separate pages of manuscripts he viewed personally, indicate the fact that fabrications had no genuine bindings to fit the dates of copying indicated in the text. In other words, these fabrications were apparently either a set of individual sheets or notebooks, 
or had a binding manufactured by the forgers. The absence of genuine bindings can be considered to some extent a distinctive feature of the workshop producing physical forgeries.

\section{Open questions}

On what grounds and who made a decision to manufacture this or that fabrication? Has the demand, potential victims and their preferences been investigated? Who else was involved in the forgery business, apart from those directly involved in manufacturing fabrications? All of them all were members of an educated elite of the Iranian society, knew each other well, were organized in various associations, were part of the administration of state organizations and national libraries. And, the top question: how many fabrications were made? After all, none of the forgers has never (sic!) provided a full list of fabrications made by them for over 20 years, from the late 1930s to the early 1960s. And by all accounts, their performance was pretty good.

\section{The appearance of a Siyar al-muluk copy from the Nakhjavani collection}

A copy of Siyar al-muluk from the Nakhjavani collection appears in the interval of maximum range between 1334-1337/1955-1958. The first date refers to the time when the third edition of Siyar al-muluk was released in Iran, without reference to this copy, which nobody knew of before and six or seven years after that release. The second date is the time when Muhammad Nakhjavani donated his collection of manuscripts and books to the newly established Tabriz National Library in the late April 1958. In the period between these two dates the copy enters the collection of Muhammad Nakhjavani, i.e., a year before the publication of Minuwi's "Kapus-nama-yi Frye" (1956) and five years before the release of his "Critical note" (1963).

The discovery of a new copy in the midst of a physical forgery scandal is not in the least indicative in itself. Also, nothing is proved by the fact that its existence first became known to a foreigner rather than Iranian specialists, who had previously published Siyar al-muluk, including Mujtaba Minuwi. It suggests analogies with the Diwan by Mu'izzi and the Qabus-nama, for which the existence of the "oldest" copies became known to Iranian experts only after they were moved abroad, completely or partially. However, all this could be a simple coincidence. But in combination with the facts cited in the Introduction to the first book of the announced series, the physical authenticity of this manuscript raises grave doubts.

\section{Methods to detect fabrications}

Modern methods of identifying fabrications have gone far ahead, as compared with those used in the $20^{\text {th }}$ century. Therefore, visual signs of a forgery are no longer the final proof for its identification. An expert assessment by guess-work will satisfy and convince nobody. One expert has more experience, while another has less. As already shown above, expert opinions can be diametrically opposite. Today, in order to eliminate the human factor as much as possible, the questionable artifacts of the written tradition are examined in several directions. 
1. Comprehensive multidisciplinary source study analysis. Some disciplines were separated into independent areas of scientific analysis; others shifted to the digital domain due to the development of digital humanities $(\mathrm{DH})$. The general principle underlying these sciences is digitizing everything that can be digitized and creating a representative database. And the general algorithm is the comparison of heterogeneous statistics generated by processing a huge data arrays. Preparing a database for automated analysis and retrieving desired statistics is the most time consuming part of operations in any $\mathrm{DH}$ area.

At present, the stage of placement of scanned (PDF) Arabographic texts published in the pre-digital era ( $20^{\text {th }}$ century) on dedicated websites is actually finalized. The technical issue of their optical recognition (OCR) and full digitization is being successfully solved and the required database is under creation. In other words, the corpus of many thousands of medieval Arabographic works gains a new life, this time in digital form. All these processes somewhat remind of a short transitional period from lithographed editions $\left(19^{\text {th }}-\right.$ early $20^{\text {th }}$ centuries $)$ to typesetting. Today, we face another dynamic change of the media with a clear trend to increase its accessibility: memory $\rightarrow$ manuscript $\rightarrow$ lithography $\rightarrow$ typesetting book $\rightarrow$ digitized text $\rightarrow \ldots$

A good database of digitized texts in a format suitable for search engines (searchable) already provides for all kinds of source research in record time [39], such as comparison of texts and the search for common locations, same persons, toponyms and terms within different texts, etc. This work was performed previously in the analysis of written sources. This includes a list of books used by the author, citing common locations, text pointers, concordances, various kinds of special-purpose dictionaries, limited by some timeframe, school or even by the author, etc. But the indisputable advantage of automated comparison is the speed of processing a huge amount of uploaded data. For instance, the Chastotnyi slovar' Unsuri (The 'Unsuri Frequency Dictionary, 1970) was compiled by its author, M.-N. O. Osmanov (d. 2015), for more than one year. Today, with all the digitized texts by the Ghaznavid court poet Abu'l-Qasim 'Unsuri (d. 431/1039), the same dictionary can be generated in a couple of hours. The difference is obvious.

Programs developed for digitizing the pre-scanned printed texts can be possibly adapted for optical recognition of the medieval handwritten texts. But so far we can only dream of some breakthroughs in the recognition and digitization of several thousand Arabographic works, yet unpublished and copied in different languages and different handwritings. Single cases of application of computer graphology by 3-5 graphic markers of individual handwriting do not count here.

2. An independent area of source study, or rather codicology, is a comprehensive technological analysis of the material text carrier, i.e. primarily, the paper: sheet thickness; their color characteristics; surface relief; fiber length, etc. The International Association of Paper Historians (IPH) founded almost 60 years ago [40] has been very successful; its members regularly publish impressive results of recent advances, including new paper dating methods ${ }^{5}$.

With regard to physical forgeries created in Iran in the mid- $20^{\text {th }}$ century, this means that technological analysis will compare the paper of previously identified forgeries, which are still kept in the above listed manuscript repositories, with the paper of copies, whose authenticity is questioned. Indeed, in this case, fabrications were apparently made in one workshop, where paper was always produced with the same technology and from the same components.

\footnotetext{
${ }^{5}$ An overview of problems and methods [see: 41].
} 
Apart from writing material, the handwriting of an uncertain manuscript can also be subjected to technological analysis and digital graphology, if the derived results can be compared with a certain reference standard, i. e., an autograph sample. However, the number of medieval autographs survived until present is far less than the number of manuscripts copied by thousands by unknown copyists.

3. Traditional textology is also being transformed into digital format. Novel DH areas are emerging on the basis of the existing database of digitized and searchable texts, aiming at their multifaceted machine analysis. This is a computer text diagnostics, which somewhat resembles the computed tomography of physical organs. It will not only allow, but also require a qualitatively new level of critical attitude to the texts of specified authors, avoiding a blind trust in what came to us under their authorship. At the same time, the limitations of such diagnostic applications are already visible.

\section{Stylometry}

Stylometry makes one of the directions in the computer text diagnostics. Various types of stylometry software are being developed in different countries, which operate with the authorial signal, or the author's fingerprint. It is detected by measuring the most frequent words (MFW), combinations of two or more words and other markers appropriate for automated processing and producing the desired statistics. With regard to the identifying fabrications, this means that the program is first trained to identify foot features in an authentic text(s). Then it compares the identified foot features with those in the doubtful text. The language, fonts and text direction (from right to left or vice versa) is absolutely unimportant for automated processing.

However, the objective limitations of stylometry application are already obvious. Its main disadvantage is a fairly significant number of MFW needed to identify the author's signal and produce a reliable result. Starting with a certain minimum, their number should be as large as possible, and they should not be stylistically neutral.

The results of computer-aided diagnostics of the Roman de la Rose, a French poem of the XIIIth century presented in the article by Maciej Eder [42, pp. 457-469], demonstrate that stylometry can be successfully applied to identifying medieval fabrications in poetry, though if only where the MFW number is adequate for the purpose. The poem was written jointly by two authors: Jean de Meun and Guillaume de Lorris. The second author added his part to the verses of the first author and both styles were clearly identified by stylometry. In other words, we can expect that literary fabrications made by the first method, i.e., with the addition of a bulky inauthentic text to the end of the authentic part - a double-layer pie, will also be identified by stylometry.

A case study of multi-layered fabrications analysis is shown by the Queen Sophia's Bible stylometry. According to its results, given in the same article, M.Eder characterizes the book as a "multifaceted collaborative work, in which the translatorial, authorial, and scribal signals are heavily mixed". Stylometry reflected the work of five translators who had their own stylistic markers.

But there is a catch. All texts taken by M.Eder for computer diagnostics are voluminous - a lengthy poem, the Bible translation. In these cases, the authors or translators had enough space to express themselves and leave their individual fingerprints. If the machine diagnostics is applied to a multi-layered text even of an innovative tasnif (not to mention a 
compilation-ta'lif), which features a combination of synthesis and analysis, the stylometry of such text would give an erroneous result when searching for the author's fingerprint. Suppose, two thirds of the tasnif size is made of small quotations taken as illustrative and evidence base from different sources, where each quotation has its intrinsic style attributes: quotations from the Quran, statements of the Prophet Muhammad, a few quotes from his companions, etc. - their styles are different. And only the remaining one-third of the size, or even less, presents the author's original conclusions with the unique author's style. The author's fingerprint in the end of quotation series would make almost no difference from any other quotation for computer-aided analysis, even less so if placed among them. The same difficulties related to the lack of the authorial text will apparently arise with stylometry of short quatrains attributed to Khayyam.

Nevertheless, a stylometry method for relatively voluminous non-attributed qasidas of medieval Persian poets is proposed in the first book of the announced series. This method was tested on an anonymous qasida, which makes an integral part of the Siyar al-muluk at the Institute of Polish language (Instytut Języka Polskiego, PAN, Kraków). The test was kindly made by Joanna Byszuk, a member of the research team of Maciej Eder.

\section{General design of the series}

Each of the texts included in the series is opened by an analytical introduction to the translation, which considers the widest range of related issues, with emphasis on the target audience analysis. Translations are followed by the original Persian texts at the end of each book preceding the indexes and bibliography.

For the purpose of design unification in the reference and bibliographic aids and transliteration, all the books in this series follow The Chicago Manual of Style [43], long developed and adopted by most international Oriental publishing houses. The preference given to this manual is explained by the simplicity and clarity of the rules developed, on the one hand, and the attempt to achieve some uniformity throughout the national Cyrillic publications, in accordance with the principles of Western publications, on the other. Here, these rules are as follows:

1. Arabographic proper names, toponyms and original terms are given:

a) in a simplified strong transliteration, i. e., using only three vowels of the Arabic alphabet, corresponding in the spelling to three diacritic marks: fatha 'a', kasra ' $\mathrm{i}$ ', damma 'u', and their diphthongs: 'ay', 'iy', ' $u y$ ', as well as two additional signs for rendering the Arab-Persian letter 'ayn and hamza. In my opinion, transliteration with numerous diacritic marks is low-informative for the reader who does not speak Arabic or Persian, except for visualizing a set of obscure words, while an expert can understand their meaning even in a simplified transliteration, especially with the original at hand;

b) without assimilation in the Arabic definite article;

c) without a soft mark.

All this prevents mixing transliteration with transcription.

Since the translation is based on Arabographic texts, where vowels are conveyed only by the specified diacritic marks, this transliteration also includes Turkic proper 
names. Their transliteration in this work may sometimes differ from the generally accepted in Russian-language publications (for example, Seljuqs $\rightarrow$ Saljuqs, Turkan/Terken-khatun $\rightarrow$ Tarkan-khatun, etc.) and is based on the diacritic marks given in the online Persian dictionary — the Lughat-nama by 'Ali Akbar Dihkhuda (d. 1334/1956) [44, 45]. The logic is simple: medieval authors transliterated the pronunciation of the original Turkic names in Arabic script, which was not fully adapted to represent all the phonetic features of the Turkic language. But today it is the Arabographic texts that serve as originals, and not some Turkic runic artifacts, where these names could have been written in some other way.

In my opinion, such an approach to the Russian-language transmission of the Turkic proper names written with the Arabic graphics, even if in a partially distorted form, looks more reasonable and consistent than their transmission in writing through "reconstructed" transcription in Cyrillic, i. e., Russian written record of how they were probably pronounced by the Turks some 900 years ago, or how they are pronounced now.

To avoid a similar anachronism, all texts provide full formulas of eulogies and good wishes, cited by the authors after mentioning the names of prophets, imams and prominent Muslim persons, instead of their obscure abbreviations, as is done in some modern Muslim publications.

2. References to sources and studies in page notes are given at the first mention in expanded form, further - in the abbreviated form. References to Arabographic publications are given in Latin transliteration in order to avoid confusing them with published Russian translations of the same-title texts.

Preference in the reference and encyclopedic literature is given to web-based publications in the public domain that do not require registration or with minimal formal registration. The same applies to links to dedicated websites where digitized printed publications are posted (marked as 'available online at') or online versions of publications only (marked as 'online edition'). Their accessibility ensures rapid verification and clarification of the information provided, as well as to view a list of sources and studies.

Today, the accessibility, rapid verification and critical evaluation have become the main criteria for data providing. To meet these criteria, citations from sources and studies included in the analytical introduction to the texts of this series are given both in translation and in their original form.

3. All interpolations in texts are taken in square brackets, including references to the Quran. All Arabic sayings, Oriental words and terms, as well as verses and Quranic quotations, are italicized.

4. Persian originals are attached to the translations. They give the reader an opportunity to suggest, if desired, his/her own version of the translation, not limited to that published in this series. No matter how good the translation may seem, it can only bring us closer to the original, in no case replacing it, of course, if the original has reached us. At the same time, as shown by the centuries-old practice of oriental studies, everything becomes outdated with time: scholarly approaches, research findings and even translations, though their life is slightly longer. Only the original texts are never outdated - the sources that remain unchanged in the same form they were created by their authors hundreds of years ago. 


\section{References}

1. Daftary Farhad. Hasan Sabbah. Encyclopeedia Iranica. Available at: http://www.iranicaonline.org/articles/hasan-sabbah (accessed: 11.11.2019). Henceforth: Encyclopcedia Iranica - EIr.

2. 'Abd al-Jalil Qazwini Razi. Demolishment (Some pieces of defamation by the Shiite haters demolishing "Some Infamies of the Rafidites"). Ed. Mir Jalal al-Din Hussaini Urmawi Muhaddith, Tehran, 1358/1979. (In Persian)

3. Torkamany Azar, Parvin. Saljuqs: Religious Dissensions and the Results. Pazhuhish-nama-yi 'ulum-i insani, no. 51, Autumn 1385/2006, pp. 53-74. Available at: http://ensani.ir/fa/article/144047/ مذهبي-و -يبامدهاي-آن سلجوقيان-اختلافات (accessed: 11.11.2019). (In Persian)

4. Shaked S., Safa Z. Andarz and andarz literature in pre-Islamic Iran; Andarz literature in New Persian. Eir. online edn. Available at: http://www.iranicaonline.org/articles/andarz-precept-instruction-advice (accessed: 31.05.2019).

5. Khismatulin A. Amir Mu'izzi Nishapuri. The Siyasat-nama/Siyar al-muluk: A Fabrication Ascribed to Nizam al-Mulk. St. Petersburg-Moscow, Peterburgskoe vostokovedenie, Sadra Publ., 2019. (In Russian and Persian)

6. Siaset-name. The book on the rule of the XI century wazir Nizam al-Mulk. Transl. by B. N.Zakhoder. Moscow-Leningrad, Izdatel'stvo AN SSSR, 1949. Available (without proofreading after OCR) at: http:// www.vostlit.info/Texts/rus10/Siaset_name/framepred.htm (accessed: 11.11.2019). (In Russian)

7. Davarpanah Hormoz. Móezzi Nišāburi. Eir. online edn. Available at: http://www.iranicaonline.org/ articles/moezzi-nisaburi (accessed: 11.11.2019).

8. Durand-Guédy David. Malekšah. Eir. online edn. Available at: http://www.iranicaonline.org/articles/ maleksah (accessed: 11.11.2019).

9. Nizam al-Mulk. Siyar al-muluk, $2^{\text {nd }}$ ed. H.Darke, Tehran, Bungah-i tarjuma wa nashr-i kitab, 1347/1968. (In Persian). There are two introductions in the book: in Persian and in English.

10. Ra'isniya Rahim. One of the sides of biography and works of Hajj Muhammad agha Nakhjawani. $B a$ qafila-yi shawq: Arj-nama-yi duktur-i Muhammad 'Ali Muwahhid, Tehran, Sutude, 2014, pp. 537-554. Available at: http://www.mirasmaktoob.ir/sites/default/files/archive/pdf/raeesnia-rahim.pdf (accessed: 11.11.2019). (In Persian)

11. Khismatulin A. The Writings of Imam al-Ghazali. St. Petersburg-Moscow, Peterburgskoe vostokovedenie, Sadra Publ., 2017. (In Russian and Persian)

12. Likhachev D. S. with collaboration of Alekseev A. A. and Bobrov A. G. Textology (on the material of Russian literature of the $10^{\text {th }}-17^{\text {th }}$ centuries). St. Petersburg, Aletheia Publ., 2001. Available at: http://www. lihachev.ru/pic/site/files/fulltext/textologia/0070.pdf (accessed: 11.11.2019). (In Russian)

13. Petrov A.E., Shnirelman V. A. Introduction. Falsification of historical sources and construction of ethnocratic myths. Moscow, The Institute of Archaeology of the RAS Publ., 2011, pp. 5-14. Available at: http://static.iea.ras.ru/books/falysifikatsiya_istorichyeskikh_istochnikov.pdf (accessed: 11.11.2019). (In Russian)

14. Bakonina M. S. A Favorite Poet of the President. Available at: http://www.fontanka.ru/2007/06/19/053/ (accessed: 11.11.2019). (In Russian)

15. Soudavar Abolala. Forgeries i. Introduction; Oscar White Muscarella. Forgeries ii. Of pre-Islamic art; Sheila Blair. Forgeries iii. Of Islamic art; Richard Francis. Forgeries iv. Of Islamic manuscripts. Eir. online edn. Available at: http://www.iranicaonline.org/articles/forgeries-i (accessed: 11.11.2019).

16. Tor Deborah. Sanjar, Ahmad b. Malikšah. Eir. online edn. Available at: http://www.iranicaonline. org/articles/sanjar (accessed: 11.11.2019).

17. Abu'l-Hasan 'Ali al-Hujwiri. Kashfal-mahjub. Ed. by V.Zhukovskiy. Leningrad, 1929. (In Persian)

18. Jalal al-Din al-Suyuti. The Differentiator between the Composer and Plagiarist. Ed. by Hilal Naji. Beirut, 1998. (In Arabic)

19. Khismatulin A. The Medieval ta'lif: Textological analysis and translation of the Risala-yi Abdaliya by Ya'qub Charkhi. Ars Islamica. Eds A. Alikberov, M. Piotrovsky. Moscow, Vostochnaya literature Publ., 2016, pp. 392-436. Available at: http://orientalstudies.academia.edu/AlexeyKhismatulin (accessed: 11.11.2019).

(In Russian and Persian)

20. Rosenthal Fr. The Technique and Approach of Muslim Scholarship. Analecta Orientalia, 1947, issue 24 , pp. $1-74$.

21. Omidsalar Mahmoud. Minovi, Mojtaba. Eir. online edn. Available at: http://www.iranicaonline.org/ articles/minovi-mojtaba (accessed: 11.11.2019).

22. Minuwi M. A note by the expert Mujtaba Minuwi on the number of the forged manuscripts. Rahnama-yi kitab, issue 2, sal-i 6, 1342/1963, pp. 238-240; idem., ibid. in: Nama-yi Baharistan, issue 5, 1381/2002, 
pp. 191-192. Available at: http://www.ensani.ir/fa/content/259990/default.aspx (accessed: 11.11.2019). (In Persian)

23. 'Omar Khayyam. Ruba'yyat, tr. and introduction by R. M. Aliev and M.-N. Osmanov, ed. by E. Bertel's. Moscow, Vostocnhaia literature Publ., 1959. Pt. 1 - the MS faximile; Pt. 2 - the Russian translation provided with the Persian text. (In Russian and Persian)

24. Minuwi M. The Kapus-nama by Frye (an exercise in the skill of identifying the forgeries). Yaghma, issue 9, 1335/1956, pp. 449-465, pp. 481-495. Available at: http://rasekhoon.net/article/show/902513/ (accessed: 11.11.2019). (In Persian)

25. Bayani Mahdi. The Diwan of Qatran Tabrizi by Anwari Abiwardi's handwriting. Yaghma, 1329/1950, issue 11, no. 3, pp. 461-474. Available at: http://www.ensani.ir/fa/content/278733/default.aspx (accessed: 11.11.2019). (In Persian)

26. Ibn 'Abbad Sahib. An Epistle on the Right Guidance and Deviancy. Eds Husayn 'Ali Mahfuz, Muhammad Muwaqqar. Tehran, Anjuman-i farhangi-yi mihr, 1374 AH/1955 AD. (In Persian)

27. Omar Khayyam. A New Version Based upon Recent Discoveries. Ed. by A. J. Arberry. London, J. Murray, 1952.

28. Omar Khayyam. Les Robaiyyat d'Omar Khayyam de Neyshaboor, pour la première fois, traduits en vers français par Pierre Pascal d’après les plus anciens manuscrits, Roma, Éditions du Coeur Fidèle, 1958.

29. Ibn Sina, Abu 'Ali Husayn b. 'Abd Allah. The Miraj-nama by imam Fakhr Razi's handwriting. Chap-i 'aksi ba kushish-i Mahdi Bayani, Tehran, Anjuman-i dustdaran-i kitab, 1331/1952. (In Persian)

30. Rastgar Fasayi Mansur. Khayyam, Farzad and the forged manuscripts of the Rubayyat. Farhang, issue 29-32, 1378/1999, pp. 181-202. Available at: http://www.ensani.ir/fa/content/266314/default.aspx (accessed: 11.11.2019). (In Persian)

31. de Bruijn J.T.P. Kaykavus b. Eskandar. Eir. online edn. Available at: http://www.iranicaonline.org/ articles/kaykavus-onsor-maali (accessed: 11.11.2019).

32. 'Unsur al-Ma'ali Kaika’us Ibn Iskandar Ibn Qabus. The Nasihat-Nama known as Qabus-Nama. Ed. by Reuben Levy. London, Luzac, 1951 (GMS, N. S. 18).

33. Mujarrad Mujtaba. On the forged and illustrated MS of Diwan by Amir Mu'izzi in Harvard University. Guzarish-i mirath 5-6, sal-I 6, 1391/2012, pp. 87-91. Available at: http://www.mirasmaktoob.ir/fa/system/ files/nashriat/GM-54\&55-Mojarad-Noskhe-p87.pdf (accessed: 11.11.2019). (In Persian)

34. Sundermann Werner. Henning, Walter Bruno. Eir. online edn. Available at: http://www.iranicaonline.org/articles/henning-walter-bruno (accessed: 11.11.2019).

35. Frye Richard N. Greater Iran: A $20^{\text {th }}$-century Odyssey. Costa Mesa, Mazda, 2005.

36. Afšar Iraj. Eqbal Aštiani 'Abbas. Eir. online edn. Available at: http://www.iranicaonline.org/articles/ eqbal-astiani (accessed: 11.11.2019).

37. 'Azimi Habibollah, Hashemi-e Asl Helya. Examination of the kinds of forgeries and fabrications in the manuscripts provided with their examples. Ayina-yi Mirath, 1394/2015, issue 56, pp. 265-291; available online at: http://www.am-journal.ir/article_46428.html (accessed: 11.11.2019). (In Persian)

38. Monzawi 'A. N. Adib Natanzi. Eir. online edn. Available at: http://www.iranicaonline.org/articles/ adib-natanzi-badi-al-zaman-abu-abdallah-hosayn-b (accessed: 11.11.2019).

39. Romanov M. Digital Age, Digital Methods. Ars Islamica. Eds A. Alikberov, M. Piotrovsky. Moscow, Vostochnaia literature Publ., 2016, pp. 129-156.

40. The International Association of Paper Historians. Available at: http://www.paperhistory.org/index.php (accessed: 31.05.2019).

41. Balachenkova A.P., Tsypkin D. O. Possibilities of technological analysis of historical papers in source-study investigation of monuments. Vestnik of Saint Petersburg University. History, 2017, vol. 62, issue 2, pp. 375-399. https://doi.org/10.21638/11701/spbu02.2017.213. (In Russian)

42. Eder M. Rolling Stylometry. Digital Scholarship Humanities, isuue 31-3, 2016, pp. 457-469.

43. The Chicago Manual of Style Online. Available at: https://www.chicagomanualofstyle.org/home.html (accessed: 11.11.2019).

44. Sa'idi Sirjani 'A.-A. Dehkhoda, Mirza 'Ali-Akbar Qazvini. Eir. online edn. Available at: http:// www.iranicaonline.org/articles/dehkoda (accessed: 11.11.2019).

45. Dekhoda, 'A.-A. Lughat-nama. Available at: http://www.vajehyab.com/dehkhoda/ (accessed: 11.11.2019).

Received: April 10, 2019

Accepted: June 17, 2019

Author's information:

Alexey A. Khismatulin — PhD (History), Senior Researcher; khism@mail.ru 


\title{
Назидательная литература эпохи Салджукидов на персидском языке: анонс книжной серии
}

\author{
А. А. Хисматулин \\ Институт восточных рукописей РАН, \\ Российская Федерация, 191186, Санкт-Петербург, Дворцовая наб., 18
}

Для цитирования: Khismatulin A. A. The Persian Mirrors for Princes Written in the Saljuq Period: the Book Series // Вестник Санкт-Петербургского университета. Востоковедение и африканистика. 2019. Т. 11. Вып. 3. С. 321-344. https://doi.org/10.21638/spbu13.2019.306

Дается сжатая характеристика жанра, периода и классических персидских текстов, которые охвачены анонсируемой книжной серией из трех книг. 1. Амир Му'иззи Нишапури. Сийасат-нама/Сийар ал-мулук («Книга о правлении/Жития владык»): подделка, приписанная Низам ал-мулку; этот текст до сих пор издается под авторством Низам ал-мулка, выдающегося премьер-министра Салджукидов. Однако, как показывают результаты исторического, кодикологического и текстологического анализов, текст был скомпилирован Мухаммадом Му'иззи Нишапури, главой департамента поэтов при салджукидских правителях Малик-шахе и его сыне Санджаре, а затем приписан им перу убитого Низам ал-мулка с совершенно определенными целями. 2. Сочинения имама ал-Газали - это книга, включающая в себя шесть текстов, из них три подлинных: руководство-пособие для студентов, озаглавленное автором как $3 а д-и$ aхират («Путевой припас для грядущей жизни»); аутентичная часть послания ал-Газали султану Санджару под названием Насихат ал-мулук («Совет владыкам») и сборник писем имама к различным адресатам под заглавием Фаза'ил ал-анам мин раса'ил Худжжат ал-ислам («Достоинства людей из посланий Довода ислама»). Оставшиеся три текста представляют подделки: это письмо ал-Газали, до сих пор считавшееся подлинным и получившее известность в персидском оригинале и арабском переводе под двумя названиями - Эц̆, фарзанд/Аййуха ал-валад («О дитя»); компилятивное письмо к некоему правителю под названием Панд-нама («Письмо с советами»); текст, который был адресован салджукидскому султану и стал известен как самостоятельный под названием ал-Фарк байна ал-салих ва гайр ал-салих («Разница между благочестивым и неблагочестивым»), так и в качестве «второй части» Насихат ал-мулук, намеренно или механически присоединенной к аутентичному тексту. 3. Кай Кавус б. Искандар б. Кабус. Кабус-нама («Книга Кабуса») и Низами 'Арузи Самарканди. Чахар макала/ Маджма' ал-навадир («Четыре беседы/Собрание редкостей») - это книга, включающая в себя два подлинных текста. Также затрагивается проблема существования подделок в исламской средневековой литературе, их категории и способы идентификации.

Ключевые слова: назидательная литература, средневековые исламские подделки, литературные подделки, Низам ал-мулк, Амир Му'иззи, Салджукиды, ложная атрибуция,

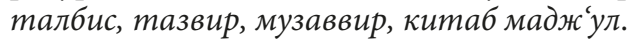

Статья поступила в редакцию 10 апреля 2019 г., рекомендована к печати 17 июня 2019 г.

Контактная информация:

Хисматулин Алексей Александрович — канд. ист. наук, старший научный сотрудник; khism@mail.ru 